\title{
Performance Evaluation of Advanced Bread Wheat Genotypes for Yield Stability Using the AMMI Stability Model
}

\section{Solomon T*, Shewaye Y, Zegeye H, Asnake D, Tadesse Z, Girma B \\ Kulumsa Agricultural Research Center, P.O.Box 489, Asela, Ethiopia}

*Corresponding author: Tafesse Solomon, Kulumsa Agricultural Research Center, P.O.Box 489, Asela, Ethiopia, Tel: +251911833888; Email: tafessesolomon@ymail.com

\section{Research Article}

Volume 3 Issue 4

Received Date: May 26, 2018

Published Date: June 15, 2018

\section{Abstract}

Bread wheat (Triticum aestivum L.) is one of the staple foods for large proportion of the Ethiopian population. Ethiopia is the largest wheat producer in Sub-Saharan Africa, The country cultivates a total of more than 1.6 million hectares, and yet imports about $1 / 3$ of the national requirement to make up for annual deficits. To increase wheat production in the country, adaptive breeding has been in progress to develop promising lines for broad adaptation or to develop wheat varieties that perform well over diverse agricultural environments. In this study a total of fifteen genotypes, eight advanced lines from CIMMYT/ICARDA source, five Ethiopian crosses, and two checks, were tested across six locations during 2017 and 2018 seasons. Yield stability index (YSI) was calculated by ranking the mean grain yield of genotypes (RY) across environments and by ranking the AMMI stability values (RASV). The smallest YSI value of 5 was exhibited by variety Hidass and entries ETBW8084, ETBW9037, ETBW9470 and ETBW8459 had YSI values of 6, 7, 12, and 12, respectively, and indicated stability across locations with comparatively higher yields. The highest YSI (30) was recorded by genotype ETBW8075 which is characterized as unstable and low yielder. ETBW 8084 was high yielder and with bi<1, (but bi is 1.236) it indicated that it will perform well in diverse environments including marginal and low yielding areas. On the other hand ETBW8075, with high deviation from regression, $\mathrm{S}_{\mathrm{i}}{ }^{2}=4.77$, was the lowest yielder and poor performance across tested locations. Therefore, ETBW8084 is recommended for production in diverse agro-ecological environments, and ETBW9470 is recommended for optimum environment. These two lines will be tested national variety verification trials (NVVT) in 2018 as candidate varieties for a possible release for production by the resource poor farmers.

Keywords: Bread Wheat; AMMI; YSI; Stability

\section{Introduction}

Bread wheat (Triticum aestivum L.), is the staple food for a large proportion of the Ethiopian population. The country is the largest wheat producer in sub- Saharan Africa, next to South Africa [1]. Wheat is found at altitudes ranging from 1700 to 2900 masl. Rainfall In these areas is bimodal and varies from 600 to $2000 \mathrm{~mm}$. Most wheat is 


\section{Open Access Journal of Agricultural Research}

produced during the main rainy season, June to September, although some is produced during the light rain season, March to May. Virtually all wheat is produced under rain fed conditions. Central and south eastern highlands of the countries are major wheat producing areas. Therefore, Arsi, Bale and part of Shoa are considered wheat growing belt.

Although Ethiopia is largest wheat producing country, the average productivity of the country is $2.5 \mathrm{t} /$ ha which is lower than world wheat productivity, $3.09 \mathrm{qt} / \mathrm{ha}$ (https://www.statista.com/statistics/237705/globalwheat-production/) and 6-7 t/h of potential farmers in the country (personal observation) [2]. Biotic stress, abiotic stress and conventional management practices are among major constraints for wheat production. In particular the breakout out of new races of wheat rusts, like Ug 99 and Digelu races throughout time made popular and wider adapted varieties out of production.

Wheat producers in developing countries, like Ethiopia which use restricted inputs and grow wheat under harsh and unpredictable environments require stable wheat varieties. The development of varieties which can be adapted to a wide range of environments with high grain yield is the final goal of any plant breeders in a crop improvement program. High yield stability usually refers to a genotype's ability to perform consistently across a wide range of environments [3]. In order to ensure consistent stability and high yields, new lines are developed, and tested for their yield performances in different environments [4]. Genotype $x$ environment interactions are of major importance, because they provide information about the effect of different environments on genotype performance and have a key role in assessment of stability of the breeding materials [5].

Quantitative trait like yield mainly dependent on $\mathrm{G} \times \mathrm{E}$ interaction as it obscures the interpretation of genetic experiments and makes predictions difficult. In such circumstances it is difficult to select and suggest one better genotype across various locations. A wider adapted Genotype performs consistently over a wider range of environment. To ensure valid genotype recommendation and to identify promising genotypes, a breeder should conduct multi location yield trials across different environments.

\section{Materials and Methods}

A total of fifteen genotypes: eight advanced genotypes initially introduced from CIMMYT and ICARDA and then evaluated and selected for four consecutive years, five Ethiopian crosses, and two checks Hidasse and Lemu were evaluated in six location: Kulumsa, Arsi robe, Assasa, Bokoji, Holota and Ofla during 2016 and 2017 cropping season. Details of each location are shown in table. A randomized complete block design with three replication was used.

\begin{tabular}{|c|c|c|c|}
\hline Entry & Genotype & Pedigree & Selection history \\
\hline 1 & Lemu & WAXWING*2/HEILO & \\
\hline 2 & ETBW8070 & Line 1 Singh/ETBW4919 & KU07-01-0KU-0KU-0KU-0BK2-22KU \\
\hline 3 & ETBW8078 & Line 1 Singh/(Cham6/WW1402) & KU07-04-0KU-0KU-0KU-0BK1-4KU \\
\hline 4 & ETBW8084 & Line 3 Singh/(Cham6/WW1402) & KU07-07-0KU-0KU-0KU-0BK1-3KU \\
\hline 5 & ETBW8311 & $\begin{array}{c}\text { ND643/2*WBLL1/3/KIRITATI//PRL/2*PASTOR/4/KIRITA } \\
\text { TI//PBW65/2*SERI.1B }\end{array}$ & $\begin{array}{l}\text { CMSS07B00823T-099TOPY-099M- } \\
\text { 099Y-099M-7WGY-0B }\end{array}$ \\
\hline 6 & ETBW8065 & Line 1 Singh/ETBW4919 & KU07-01-0KU-0KU-0KU-0BK1-5KU \\
\hline 7 & ETBW8427 & $\begin{array}{l}\text { SERI.1B//KAUZ/HEVO/3/AMAD/4/PYN/BAU//MILAN/5/I } \\
\text { CARDA-SRRL-1 }\end{array}$ & ICW06-50208-5AP-0AP-0AP -02 SD \\
\hline 8 & ETBW8459 & CHIL-1//VEE'S'/SAKER'S' & $\begin{array}{c}\text { ICW99-0026-7AP-0AP-0AP-9AP-0AP- } \\
\text { 0DZ/0AP-0DZ/0KUL/0SIN/0AP- } \\
\text { 0NJ/0AP-0ALK/0AP } \\
\end{array}$ \\
\hline 9 & ETBW9037 & SWSR22T.B./2*BLOUK \#1//WBLL1*2/KURUKU & \begin{tabular}{|c|} 
CMSS08Y01116T-099M-099Y-099M- \\
099NJ-099NJ-23WGY-0B \\
\end{tabular} \\
\hline 10 & ETBW9045 & KINDE/4/CMH75A.66//H567.71/5*PVN/3/SERI & $\begin{array}{c}\text { CMSS09Y00603S-099Y-17M-0WGY-6B } \\
\text { 0Y }\end{array}$ \\
\hline
\end{tabular}




\section{Open Access Journal of Agricultural Research}

\begin{tabular}{|c|c|c|c|}
\hline 11 & ETBW8075 & Line 1 Singh/(Cham6/WW1402) & KU07-04-0KU-0KU-0KU-0BK1-1KU \\
\hline 12 & ETBW9464 & $\begin{array}{l}\text { MARCHOUCH } * \text { /SAADA/3/2*FRET2/KUKUNA//FRET2*2/4 } \\
\text { /TRCH/SRTU//KACHU }\end{array}$ & $\begin{array}{l}\text { CMSS10B00928T-099TOPY-099M- } \\
\text { 099NJ-099NJ-13WGY-0B }\end{array}$ \\
\hline 13 & ETBW9466 & $\begin{array}{c}\text { ATTILA/3*BCN//BAV92/3/TILHI/5/BAV92/3/PRL/SARA/ } \\
\text { /TSI/VEE\#5/4/CROC_1/AE.SQUARROSA } \\
\text { (224)//2*OPATA*2/6/HUW234+LR34/PRINIA//UP2338*2 } \\
\text { /VIVITSI }\end{array}$ & $\begin{array}{l}\text { CMSS10B01047T-099TOPY-099M- } \\
\text { 099NJ-099NJ-2WGY-0B }\end{array}$ \\
\hline 14 & ETBW9470 & $\begin{array}{c}\text { BAVIS } \\
\# 1 / 5 / \text { W15.92/4/PASTOR//HXL7573/2*BAU/3/WBLL1 }\end{array}$ & $\begin{array}{l}\text { CMSA10M00485S-099ZTM-099NJ- } \\
\text { 099NJ-6WGY-0B }\end{array}$ \\
\hline 15 & Hidasse & $\begin{array}{l}\text { YANAC/3/PRL/SARA//TSI/VEE\#5/4/CROC- } \\
\text { 1/AE.SQUAROSA(224)//OPATTA }\end{array}$ & \\
\hline
\end{tabular}

Table 1: Pedigree and history of fifteen genotypes tested for yield performance and wheat rust resistance.

\begin{tabular}{|c|c|c|c|c|c|c|}
\hline \multirow{2}{*}{ Location } & \multirow{2}{*}{ Altitude (m) } & \multirow{2}{*}{ Representing Agroecology } & \multirow{2}{*}{ Soil type } & \multirow{2}{*}{ Rainfall } & \multicolumn{2}{|c|}{ Temp } \\
\cline { 4 - 7 } & & & & & max & Min \\
\hline Kulumsa & 2200 & Mid-altitude & Clay soil (luisols) & $820 \mathrm{~mm}$ & 22.8 & 10.5 \\
\hline Arsi robe & 2420 & Water logged vertisoil & Heavy clay soil (vertisiol) & $890 \mathrm{~mm}$ & 22.1 & 6 \\
\hline Assasa & 2340 & Terminal drought prone & Clay loam soil(gleysols) & $620 \mathrm{~mm}$ & 23.6 & 5.8 \\
\hline Bokoji & 2780 & Highland/haigh rainfall & Clay siol(nitosols) & $1020 \mathrm{~mm}$ & 18.6 & 7.9 \\
\hline Holota & 2400 & M2-5 & Nitosols & 1144 & 22 & 6 \\
\hline Ofla & 2490 & - & clay & - & 22.2 & 7.7 \\
\hline
\end{tabular}

Table 2: Information on Altitude, Soil, rainfall and temperature of tested location.

\section{Statistical Analysis}

Four internal rows were harvested and grain yield per plot was converted to ton per hectare. Analysis of Variance was computed to determine the effects of genotype, environment, and GE interactions on grain yield. The stability of yield performance for each genotype was calculated by regressing the mean grain yield of individual genotypes on environ-mental index and calculating the deviation from regression as suggested by Eberhart and Russell as [6]:

$$
Y_{i j}=\mu_{i}+\beta_{i} I_{j}+\delta_{i j}
$$

where: $Y_{i j}$ is the variety mean of the $i^{\text {th }}$ environment, $\mu_{\mathrm{i}}$ is the mean of $i^{\text {th }}$ variety over all environments, $\beta_{i}$ is the regression coefficient that measures the responseof the $i^{\text {th }}$ variety to varying environments, $\delta_{\mathrm{ij}}$ is the deviation from regression of the $i^{\text {th }}$ variety at the $j^{\text {th }}$ environment, and $\mathrm{I}_{\mathrm{j}}$ is the environmental index obtained as the mean of all varieties at the $j^{\text {th }}$ environment minus the grand mean. regression coefficient (bi) close to unity and deviation from regression $\left(\mathrm{S}^{2} \mathrm{~d}_{\mathrm{i}}\right)$ near to zero, was defined as a stable cultivar [6].
AMMI Stability Value (ASV is the distance from the coordinate point to the origin in a two-dimensional plot of IPCA1 scores against IPCA2 scores in the AMMI model [7]. Because the IPCA1 score contributes more to the GXE interaction sum of squares, a weighted value is needed. This weighted value was calculated for each genotype and each environment according to the relative contribution of IPCA1 to IPCA2 to the interaction sum of squares as follows:

$$
\mathrm{ASV}=\sqrt{\left[\left(S_{I P C A 1} \div S S_{I P C A 2}\right)(\text { IPCA1score })^{2}+(\text { IPCA2score })^{2}\right]}
$$

where, $\mathrm{SS}_{\mathrm{IPCA} 1} / \mathrm{SS}_{\mathrm{IPCA} 2}$ is the weight given to the IPCA1value by dividing the IPCA 1 sum of squares by the IPCA2 sum of squares. Either the larger negative ASV value or positive, the more specifically adapted a genotype is to certain environments. Smaller ASV values indicate more stable genotypes across environments [7].

Yield stability index (YSI), is calculated by ranking the mean grain yield of genotypes (RY) across environments and rank of AMMI stability value (ASV). The YSI 


\section{Open Access Journal of Agricultural Research}

incorporates both mean yield and stability in a single criterion as follows: YSI $=$ RASV + RY $[8,9]$. Ecovalnce
$\left(W_{i}^{2}\right)$ and stability variance $(\sigma i 2)$ were computed as suggested by Wricks's and Shukla's [10,11].

\section{Result and Discussion}

\begin{tabular}{|c|c|c|c|c|c|c|c|c|c|c|}
\hline GEN & Mean & ASV & YSI & RASV & RYI & $\boldsymbol{W}_{\boldsymbol{i}}{ }^{\mathbf{2}}$ & $\boldsymbol{\sigma i 2}$ & $\mathbf{s i}_{\mathbf{2}}{ }^{2}$ & $\mathbf{b i j}$ & $\mathbf{S d}^{2} \mathbf{i}$ \\
\hline Lemu & 5.17 & 0.6834 & 14 & 5 & 9 & 17.26 & $3.662091 \mathrm{~ns}$ & $1.818214 \mathrm{~ns}$ & 0.408 & 0.21 \\
\hline ETBW8070 & 5.61 & 1.3542 & 20 & 14 & 6 & 30.56 & $6.731099 \mathrm{~ns}$ & $4.355622 \mathrm{~ns}$ & 0.286 & 0.008 \\
\hline ETBW8078 & 4.19 & 0.8852 & 21 & 8 & 13 & 14.46 & $3.016039 \mathrm{~ns}$ & $3.570220 \mathrm{~ns}$ & 0.807 & 0.006 \\
\hline ETBW8084 & 6.04 & 0.4525 & 6 & 4 & 2 & 5.68 & $0.991338 \mathrm{~ns}$ & $0.892331 \mathrm{~ns}$ & 1.236 & 0.434 \\
\hline ETBW8311 & 4.04 & 0.9258 & 24 & 10 & 14 & 22.6 & $4.890277 \mathrm{~ns}$ & $5.565642 \mathrm{~ns}$ & 1.283 & 0.123 \\
\hline ETBW8065 & 5.05 & 1.3461 & 23 & 13 & 10 & 31.39 & $6.923159 \mathrm{~ns}$ & $7.167105 \mathrm{~ns}$ & 0.559 & 0.491 \\
\hline ETBW8427 & 5.66 & 0.8858 & 14 & 9 & 5 & 12.89 & $2.652924 \mathrm{~ns}$ & $2.987167 \mathrm{~ns}$ & 0.77 & 0.042 \\
\hline ETBW8459 & 5.02 & 0.093 & 12 & 1 & 11 & 7.91 & $1.505092 \mathrm{~ns}$ & $1.909821 \mathrm{~ns}$ & 1.097 & 0.192 \\
\hline ETBW9037 & 5.74 & 0.3589 & 7 & 3 & 4 & 4.36 & $0.684794 \mathrm{~ns}$ & $0.950139 \mathrm{~ns}$ & 0.962 & 0.418 \\
\hline ETBW9045 & 5.41 & 0.7073 & 13 & 6 & 7 & 12.3 & $2.517762 \mathrm{~ns}$ & $3.215418 \mathrm{~ns}$ & 1.068 & 0.024 \\
\hline ETBW8075 & 2.35 & 1.6888 & 30 & 15 & 15 & 55.26 & $12.430907 * *$ & $14.024556 * *$ & 0.555 & 4.779 \\
\hline ETBW9464 & 4.5 & 1.2541 & 24 & 12 & 12 & 31.54 & $6.959196 \mathrm{~ns}$ & $5.583620 \mathrm{~ns}$ & 1.623 & 0.128 \\
\hline ETBW9466 & 5.24 & 0.7975 & 15 & 7 & 8 & 14.44 & $3.013000 \mathrm{~ns}$ & $1.164301 \mathrm{~ns}$ & 1.576 & 0.36 \\
\hline ETBW9470 & 7.13 & 1.1078 & 12 & 11 & 1 & 25.87 & $5.649403 \mathrm{~ns}$ & $3.096933 \mathrm{~ns}$ & 1.706 & 0.033 \\
\hline Hidasse & 6 & 0.2096 & 5 & 2 & 3 & 5.06 & $0.847359 \mathrm{~ns}$ & $1.133583 \mathrm{~ns}$ & 1.062 & 0.368 \\
\hline
\end{tabular}

Table 3: Results of AMMI stability values.

mean= mean grain yield, ASV=AMMI stability value, $Y S I=$ yield stability index , RASI= rank of AMMI stability value RYI= rank of yield index, Wi2= Wrick's ecovalance, $\sigma \mathrm{i} 2=$ Shukla's stability, $\mathrm{s}_{\mathrm{i}}{ }^{2}=$ stability variance, bij=regression coefficient and $\mathrm{Sd}_{\mathrm{i}}=$ deviation from regression.

Lemu and Hidase, released varieties in 2016 and 2012 respectively by Kulumsa Agricultural Research Center (KARC) were used as checks. Most of the time genotypes showed inconsistency in rank of grain yield across different tested environment; genotype ranked first in one environment may not be first at another tested environment. and hence, It is advantageous to look for a single criteria which help researchers to identify elite genotypes simultaneously for their high yielding and stable across tested environment. YSI is a single criteria for stability and high grain yield which successfully used by Bose, et al., Bavandpori, et al., to interpret interaction between genotype performance and environments $[8,9]$. High yielding genotype with better stability has smallest values of YSI. The smallest Yield stability index (YSI) exhibited by variety Hidasse (YSI=5) and Advanced genotypes: ETBW8084 (YSI=6), ETBW9037 (YSI=7), ETBW9470(YSI=12) and ETBW8459(YSI=12). These genotypes were high yielder and comparatively stable. The Highest YSI(YSI=30) exhibited by genotype ETBW
8075 which was highly unstable and lowest yielder among tested genotypes.

As suggested by Wricke, ecovalance $\left(W_{l}^{2}\right)$ used as stability parameters [10]. The smaller the values, the stable the genotype was. The $\mathrm{W}_{\mathrm{i}}{ }^{2}$ was lower for ETBW9037 $W_{i}^{2}(=4.36)$, Hidasee $\left(\mathrm{W}_{\mathrm{i}}{ }^{2}=5.06\right)$, ETBW8084 $\left(\mathrm{W}_{\mathrm{i}}{ }^{2}=5.68\right)$, ETBW8459 $=\left(W_{i}{ }^{2}=7.91\right)$, so that, they are stable. Like Ecovalance, the stability variance $\mathrm{S}_{\mathrm{i}}{ }^{2}$ also showed that smaller values for ETBW8084 $\left(\mathrm{S}_{\mathrm{i}}{ }^{2}=0.89\right)$, ETBW9037 $\left(\mathrm{S}_{\mathrm{i}}{ }^{2}=0.95\right)$ and Hidasse $\left(\mathrm{S}_{\mathrm{i}}{ }^{2}=1.13\right)$ [12]. The ecovalance and the stability variance gave nearly similar results and have positive correlation as proved by Kilic $\mathrm{H}$. et al [13].

Awidely adapted cultivar had high mean grain yield, regression coefficient close to unity and deviation from regression coefficient near to zero [6]. ETBW9470, with highest mean grain yield exhibited higher regression coefficient, $b_{i}>1$, which means this genotype was widely 


\section{Open Access Journal of Agricultural Research}

adapted to high yielding environments or optimum areas. A cultivar Hidase, genotypes: ETBW9045, ETBW8084 and ETBW8427 were high yielder and bi close to unity and $\mathrm{S}_{\mathrm{i}}{ }^{2}$ near to zero. And therefore, they were widely adapted genotypes. ETBW 8084 was high yielder and $\mathrm{bi}<1$, indicted that the genotype well perform to environmental changes and low yielding areas [14]. ETBW8075 with high deviation from regression $\mathrm{S}_{\mathrm{i}}{ }^{2}=4.779$ (table.) delivered the lowest yield and poor performance across tested location.

\begin{tabular}{|c|c|c|c|c|c|c|}
\hline Genotypes & Arsirobe & Assasa & Bokoji & Holota & Kulumsa & Ofla \\
\hline Lemu & 4.6 & 5.2875 & 4.8125 & 4.9625 & 6.675 & 4.685714 \\
\hline ETBW8070 & 4.9125 & 6.85 & 6.7 & 4.7625 & 5.625 & 4.785714 \\
\hline ETBW8078 & 3.8375 & 4.5125 & 2.575 & 3.0625 & 5.6375 & 5.514286 \\
\hline ETBW8084 & 6.8375 & 6.7 & 5.1625 & 3.55 & 7.9875 & 5.985714 \\
\hline ETBW8311 & 4.4375 & 5.9 & 1.4375 & 2.1125 & 5.2 & 5.171429 \\
\hline ETBW8065 & 3.9 & 6.8625 & 5.925 & 4.1125 & 5.8 & 3.685714 \\
\hline ETBW8427 & 5.725 & 6.975 & 6.1375 & 3.9875 & 6.625 & 4.5 \\
\hline ETBW8459 & 5.375 & 6.3625 & 4.8 & 2.2625 & 5.775 & 5.557143 \\
\hline ETBW9037 & 6.2375 & 6.575 & 5.2625 & 4 & 7.4125 & 4.942857 \\
\hline ETBW9045 & 4.8375 & 7.4875 & 5.6625 & 3.1875 & 6.475 & 4.828571 \\
\hline ETBW8075 & 1.5125 & 2.0375 & 0.8625 & 1.2 & 3 & 5.485714 \\
\hline ETBW9464 & 5.3625 & 6.05 & 1.425 & 2.3125 & 7.025 & 4.814286 \\
\hline ETBW9466 & 5.65 & 6.1125 & 3.775 & 2.5375 & 8.15 & 5.242857 \\
\hline ETBW9470 & 8.4 & 8.725 & 6.5286 & 3.4375 & 9.325 & 6.371429 \\
\hline Hidasse & 6.0625 & 6.2 & 5.4 & 3.925 & 8.1 & 6.328571 \\
\hline
\end{tabular}

Table 4: Mean grain yield of fifteen genotypes across six location for two years.

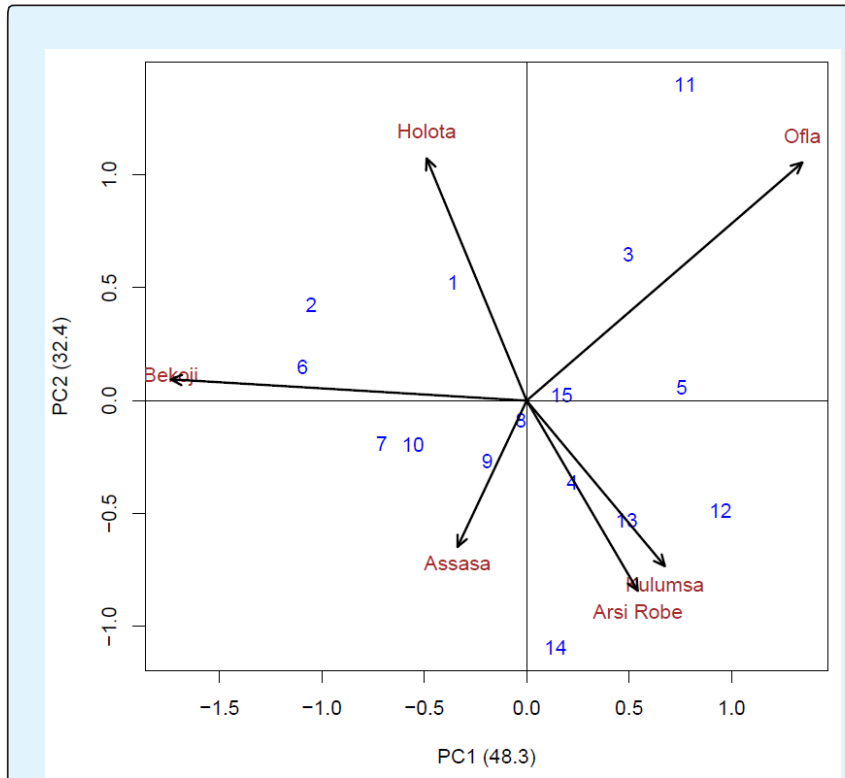

Figure 2: A graphical analysis was generated and used.

Mean grain yield for two years ranges from the highest 9.33t $/$ ha to the smallest $0.86 \mathrm{t} / \mathrm{ha}$. The highest grain yield performed By genotype ETBW9470 at Kulumsa and the lowest grain yield delivered by genotype ETBW 8075 at Bokoji. Mean grain yield for tested genotypes were lower relative to other location. The high incidence of Septoria was to saw the interaction effect, a graphical analysis was generated and used (fig.). Graphical result from AMMI model showed that the first principal component PC1, explained $48.3 \%$ of interaction some of square while the second principal component,PC2 explained $32.4 \%$ of some of square interaction(Fig. ). The first two principal component together addressed $80.7 \%$ of interaction effect which indicate the majority of interaction fell on PC1 and PC2 [15-31].

\section{Conclusion and Recommendation}

To develop varieties for different environments, very essential for breeders to evaluate their genotypes based on many years and several locations. Environmental variations are important in determining performance of elite materials. Genotype ranks consistently across different tested location has less response for highly unstable environment. Genotype 8084 is high yielder than the two checks and stable across tested location. Therefore this genotypes recommended as candidate variety for next year to release as a variety for wider 


\section{Open Access Journal of Agricultural Research}

environment. Genotype 9470 with highest mean grain yield and best performance at potential environments recommended as candidate variety for optimum areas.

\section{Acknowledgement}

This work would not have been possible without the financial support EIAR, Collaborating regional and federal research centers and wheat breeding teams of Kulumsa Agricultural Research Center (KARC). I am grateful to all of those with whom I have had the pleasure to work during this and other related projects.

\section{References}

1. White JW, Tanner DG, Corbett JD (2011) An agroclimatological characterization of bread wheat production areas in Ethiopia. CIMMYT, México, US.

2. CSA (2010) Agricultural sample survey report on area, production and yields of major crops. Central statistical Authority, Addis Ababa, Ethiopia.

3. Annicchiarico P (1997) Additive main effects and multiplicative interaction (AMMI) analysis of genotype location interaction in variety trials repeated over years. Theoretical and Applied Genetics 94(8): 1072-1077.

4. Mehmet A, Telat Y (2006) Adaptability performance of some bread wheat (Triticum aestivum L.) genotypes in the Eastern region of Turkey. Turk Int J Sci \& Technol 1(2): 82-89.

5. Moldovan V, Moldovan M, Kadar R (2000) Item from Romania. S:C:A Agricultural Research Station.

6. Eberhart SA, Russell WA (1966) Stability parameters for comparing varieties. Crop Sci 6(1): 36-40.

7. Purchase JL, Hatting H, Vandeventer CS (2000) Genotype $\times$ environment interaction of winter wheat (Triticum aestivum L.) in South Africa: Stability analysis of yield performance. South African Journal of Plant and Soil 17(3): 101-107.

8. Bose LK, Jambhulkar NN, Pande K, Sing ON (2014) Use of AMMI and other stability statistics in the simultaneous selection of rice genotypes for yield and stability under direct-seeded conditions. Chilean Journal of Agricultural Research 74(1).
9. Bavandpori F, Ahmadi J, Hossaini SM (2015) Yield Stability Analysis of Bread Wheat Lines using AMMI Model. Agricultural Communications 3(1): 8-15.

10. Wricke G (1962) On a method of understanding the biological diversity in field research. Z Pflanzenzucht 47: 92-96.

11. Shukla GK (1972) Some statistical aspects of partitioning G x E components of variability. Heredity 29(2): 237-245.

12. Becker HC, Leon J (1988) Stability analysis in plant breeding, Plant Breed 101: 1-23.

13. Kılıç H (2012) Assessment of Parametric and Non parametric methods for Selecting Stable and Adapted Spring Bread Wheat Genotype in Multi-Environments. Journal of Animal \& Plant Sciences 22(2): 390-398.

14. Singh RP, Hodson DP, Huerta-Espino J, Jin Y, Bhavani S, et al. (2011) The Emergence of Ug99 Races of the Stem Rust Fungus is a Threat to World Wheat Production. Annu Rev Phytopathol 49(1): 465-481.

15. Ahmed J, Choudhery MH, Salah-ud-Din S, Ali MA (1996) Stability for grain yield in wheat. Pak. J Bot. 28(1): 61-65.

16. Akcura M, Kaya Y, Taner S, Ayranci R (2006) Parametric stability analyses for grain yield of durum wheat. Plant Soil Environ 52(6): 254-261.

17. Allard RW, Bradshaw AD (1964) Implication of genotype $\mathrm{x}$ environmental interaction in applied plant breeding. Crop Sci 5: 503-508.

18. Food and Agriculture Organization of the United Nations FAO. Rome, Italy pp: 519-564.

19. Ceccarelli S, Grando S, Booth RH (2006) International breeding programmes and resource-poor farmers: crop improvement in difficult environments. The International Center for Agricultural Research in the Dry Areas (ICARDA), Aleppo, Syria pp: 189-199.

20. Freeman GH (1990) Modern statistical methods for analyzing genotype-environment interactions. In: Kang MS (Ed.), Genotype $\times$ Environment Interaction and Plant Breeding pp: 118-125.

21. Gauch HG, Piepho HP, Annicchiaricoc P (2008) Statistical analysis of yield trials by AMMI and GGE: Further considerations. Crop Sci 48(3): 866-889. 


\section{Open Access Journal of Agricultural Research}

22. Kang MS (1992) Simultaneous selection for yield and stability: Consequences for growers. Agron J 85(3): 754-757.

23. Khan AJ, Azam F, Ali A, Tariq M, Amin M, et al. (2007) Wide and specific adaptation of bread wheat inbred lines for yield under rainfed conditions. Pak J Bot 39(1): 67-71.

24. Lillimo M, van Ginkel M, Trethowan RM, Hernandez E, Rajaram S (2003) Associations among international CIMMYT bread wheat yield testing locations in high rainfall areas and their implications for wheat breeding. Crop Sci 44(4): 1163-1169.

25. Mohammadi R, Abdulahi A, Haghparast R, Armion M (2007) Interpreting genotype $X$ environment interactions for durum wheat grain yields using nonparametric methods. Euphytica 157(1-2): 239-251.

26. Nachit MM, Nachit G, Ketata H, Gauch HG, Zobel RW (1992) Use of AMMI and linear regression models to analyse genotype environment interaction in durum wheat. Theor Appl Gene 83(5): 597-601.

27. Naghavi A, Sofalian O, Asghari A, Sedghi M (2010) Relation between freezing tolerance and seed storage proteins in winter bread wheat (Triticum aestivum L.). Turk J Fld Cr 15(2): 154-158.

28. R Development Core Team (2008) R: A language and environment for statistical computing. R Foundation for Statistical Computing, Vienna, Austria.

29. Singh RK, Chaudhary BD (1985) Biometrical methods in quantitative genetics. Kalyani Publishers, New Dehli, India.

30. Steel RGD, Torrie JH, Deekey DA (1997) Principles and Procedures of Statistics: A Biometrical Approach. 3rd Edition. McGraw Hill book Co Inc pp: 666.

31. Yan W, Rajcan I (2002) Biplot analysis of test sites and trait relations of Soybean in Ontario. Crop Sci 42(1): 11-20. 